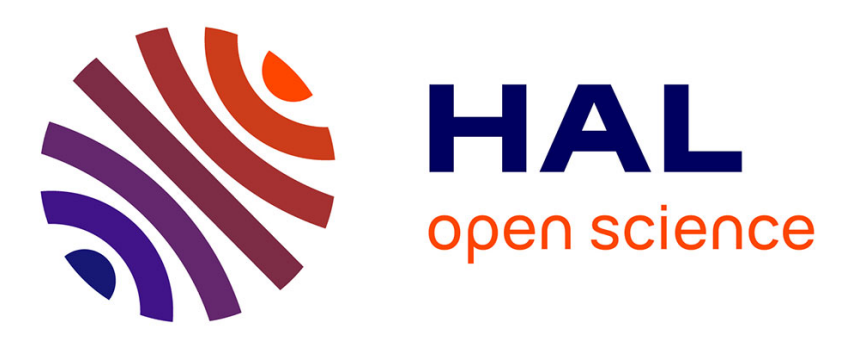

\title{
3D Geological modelling and gravity inversion of a structurally complex carbonate area: Application for karstified massif localization
}

Eglantine Husson, Antonio Guillen, Gabriel Courrioux, Renaud Couëffé, Michel Seranne

\section{To cite this version:}

Eglantine Husson, Antonio Guillen, Gabriel Courrioux, Renaud Couëffé, Michel Seranne. 3D Geological modelling and gravity inversion of a structurally complex carbonate area: Application for karstified massif localization. 4th meeting of the European 3D GeoModelling Community, Feb 2018, Orléans, France. hal-01708169

\section{HAL Id: hal-01708169 https: / hal-brgm.archives-ouvertes.fr/hal-01708169}

Submitted on 13 Feb 2018

HAL is a multi-disciplinary open access archive for the deposit and dissemination of scientific research documents, whether they are published or not. The documents may come from teaching and research institutions in France or abroad, or from public or private research centers.
L'archive ouverte pluridisciplinaire HAL, est destinée au dépôt et à la diffusion de documents scientifiques de niveau recherche, publiés ou non, émanant des établissements d'enseignement et de recherche français ou étrangers, des laboratoires publics ou privés. 


\title{
3D Geological modelling and gravity inversion of a structurally complex carbonate area: Application for karstified massif localization
}

\author{
Eglantine Husson ${ }^{1}$, Antonio Guillen ${ }^{1}$, Michel Séranne ${ }^{2}$, Gabriel Courrioux ${ }^{1}$, Renaud Couëffé ${ }^{1}$.
}

\author{
BRGM - 3, avenue C. Guillemin, 45060 Orléans Cedex 2, France. \\ ${ }^{2}$ Géosciences Montpellier, CC060, Université Montpellier II, 34095 Montpellier Cedex 05, France.
}

In Languedoc (S. France), significant water resources are found in karstified limestones of mostly Late Jurassic age, deposited as platform carbonate on the Tethyan margin (Maréchal et al., 2013). The area is structurally complex, as a result of polyphase cover tectonics, including uplift, folding and reverse faulting, as well as extensional bloc-faulting and subsidence. From midCretaceous, up to 4 phases of karstification have affected the carbonates, when and where they were exposed (Husson, 2013). The need for increased water resources leads to target deep karsts buried beneath younger sedimentary cover. We propose a new methodology to improve the location of potential karstified areas by gravity inversion of a 3D geological model.

The model covers $70 \times 30 \mathrm{~km}$ area which encompasses the structural complexity; it is $5.5 \mathrm{~km}$ thick, in order to include the entire post-Palaeozoic sedimentary cover. The available data comprise: $1 / 250.000$ and $1 / 50.000$ geological maps, about $250 \mathrm{~km}$ of reprocessed 2D seismic reflection profiles, 14 petroleum exploration boreholes, 693 shallower boreholes, and gravimetric survey. In area devoid of seismic reflection data, depth sections were drawn from surface geological maps and borehole data, where available. Regional geology provided a general template and constraints while building the 3D model. The stratigraphy for the model distinguishes 11 intervals with either reservoir or seal characteristics. The structural framework is compartmented by 37 major faults.

The model is built by integrating field-based or seismic reflection-based geological sections. Modeling with 3D GeoModeller allowed us to check for inconsistencies within the input data. For example, although some sections may be consistent as a 2D construction, they fail to be integrated in a coherent 3D model. Further, there are several difficulties that 3D GeoModeller helps overcome, especially in the poorly documented areas: not imaged by seismic, or distant from borehole data, or cover by recent alluvium. In that case, the model computes the simplest geometrical solution by interpolation of the nearest data. Such solution can be confirmed or modified by the user, according to geological interpretation and gravimetric data interpretation, imported in the software.

Its theoretical gravimetric response is compared to gravity field during the forward problem in order to evaluate the validity/robustness of the geological model. The coherency between the gravity field and the gravimetric response is tested. The litho-inversion modelling quantifies the distribution of rock density in a probabilistic way, taking into account the geology and physical properties of rocks, while respecting the geological structures represented in the 3D model. The result of the inversion process provides a density distribution within carbonate formations that can be discussed in term of karstification distribution. Thus, lower densities correlate with areas that are strongly karstified. Conversely, higher than mean densities are found in carbonate formations mostly located under marly and impervious formations, preserving carbonate from karstification and paleokarstification.

Husson, E. (2013) Interaction géodynamique/karstification et modélisation géologique 3D des massifs carbonates : Implication sur la distribution prévisionnelle de la karstification. Exemple des paléokarsts crétacés à néogènes du Languedoc montpelliérain. Thèse de doctorat, Univ Montpellier II, 316 pp.

Marechal, J. C., Vestier, A., Jourde, H. and Dörfliger, N. (2013) L'hydrosystème du Lez: une gestion active pour un karst à enjeux. Karstologia, 62, 1-6. 

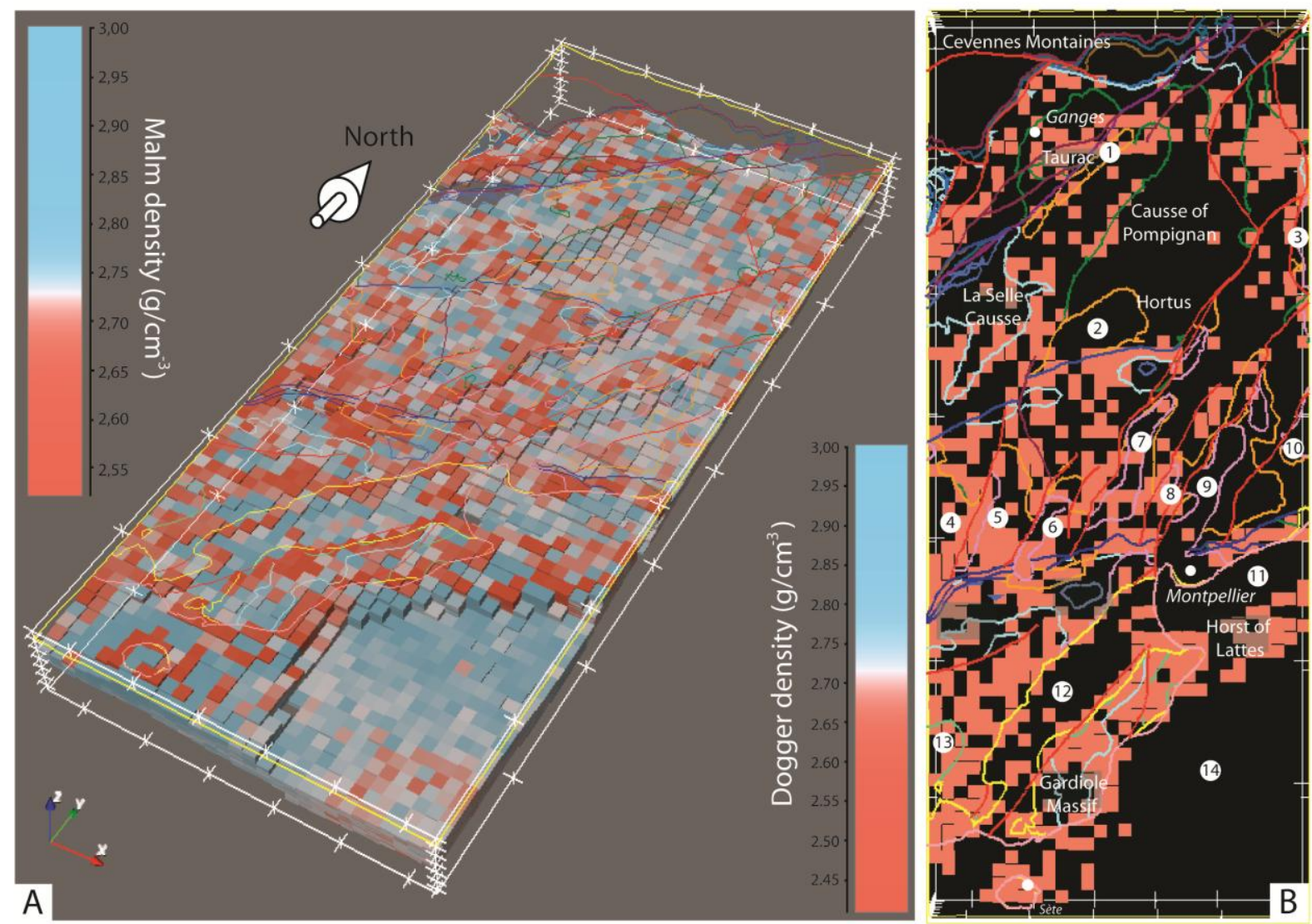

Figure 1 : A) Perspective display of the 3D distribution of calculated densities for the Jurassic formations (Malm and Dogger). The color for each cell $(1 \times 1 \times 0.7 \mathrm{~km})$ gives the density values higher (in blue) or lower (in red) than the mean density value of the formation (in white). B) Map of lower density cells of Malm and Dogger formations (in red), corresponding to values of mean density minus one sigma value. They are located in areas of known (La Selle Causse or Gardiole Massif) or inferred (Horst of Lattes) karstification. By contrast, areas such as "Causse de Pompignan" where the Malm formation is covered by impervious Early Cetaceous marls do not display lower than mean values of density. We interpret low density areas as intensely karstified parts of carbonate formations. 